\title{
ASSESSING THE LONG TERM STABILITY OF THE DEPOLARIZATION CONSTANT FOR THE CLUJ STATION
}

\author{
H. Stefanie ${ }^{1^{*}}$, N. Ajtai ${ }^{1}$, A. Radovici ${ }^{1}$, D. Ene ${ }^{2}$, L. Belegante ${ }^{2}$ \\ ${ }^{l}$ Faculty of Environmental Science and Engineering, Babeș-Bolyai University, Cluj-Napoca, Romania, \\ ${ }^{2}$ National Institute for Research and Development in Optoelectronics INOE 2000 Magurele, Romania \\ *Email: horatiu.stefanie@ubbcluj.ro
}

\begin{abstract}
The study aims to assess the additional systematic error caused by the assessment of the depolarization constant. Based on the long time assessment of this constant, a mean value and a standard deviation can be retrieved. A sensitivity study could assess the deviation of the depolarization value in high and low depolarizing atmospheric layers. Based on these deviations, the systematic error of the calibration is retrieved and included in the final depolarization products.
\end{abstract}

\section{INTRODUCTION}

At the present state, the LIDAR systems have different configurations and geometries, according to their applications. The multiwavelength Raman and depolarization LIDAR systems used in the European Aerosol Research Lidar Network - EARLINET [2] are suitable to provide an extended set of optical parameters for aerosol characterization which can be used in climatology studies, models and different events like Saharan dust outbreaks, transport of smoke plumes or volcanic ash $[3,4,6]$.

The study aims to assess the long term stability of the depolarization constant for the Cluj lidar station and retrieve the additional systematic error from the assessment of this constant $[1,5]$. For this study, daily depolarization calibrations were performed over an extended time period.

\section{METHODOLOGY}

\subsection{The lidar system}

The Cluj-Napoca lidar (CLOP) emission system is based on a Nd:YAG laser (Continuum INLITE II -30 ) with a repetition rate of $30 \mathrm{~Hz}$, equipped with second and third harmonics. The laser beams at $1064 \mathrm{~nm}, 532 \mathrm{~nm}$ and $355 \mathrm{~nm}$ are simultaneously emitted into atmosphere. Currently no beam expander is mounted on the instrument's emission unit.
The backscattered radiation is collected by a Raymetrics D300 Cassegrain type telescope with a focal length of $1500 \mathrm{~mm}$. The signal detection unit has 4 detection channels for the elastically backscattered radiation at 1064, 532 (cross and parallel) and $355 \mathrm{~nm}$ and 2 detection channels for the Raman radiation backscattered from the N2 molecules at 607 and $386 \mathrm{~nm}$.

\subsection{Calibration of the depolarization channels}

The calibration of the depolarization channels is performed using a mechanical rotator in front of the wavelength separation module. The calibration consists in performing two consecutive $\Delta 90^{\circ}$ according to Freudenthaler (2016).

\section{RESULTS AND DISCUSSIONS}

Figure 1 shows the variation of the depolarization constant over a period of more than one month. The data shows large deviations during the first calibration sets, a $20 \%$ deviation over the next 20 days and a decreased deviation for the remaining 8 days $(<10 \%)$. The mean value for the depolarization constant is 0.4 with an overall deviation of $0.1(25 \%)$.

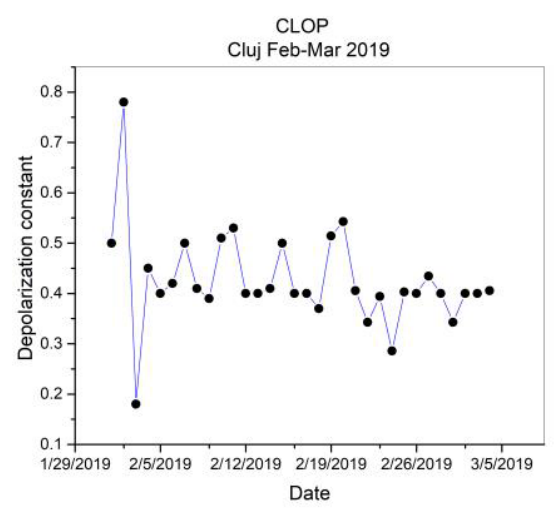

Figure 1 Depolarization constant values over extended time period

Different relative deviations over different time periods could indicate either external factors like 
instrument alignments or could simply indicate changes to the measurement setup (signal intensity or integration times).

Further on for the study, a mean value of 0.4 for the depolarization constant and a 0.1 error were considered.

Fig $2 \mathrm{a}, \mathrm{b}$ shows the error of the depolarization profile for 24.02.2019. The sensitivity study shows that the error of the high depolarizing layers is more affected by the accuracy of the retrieval than the error of the low depolarizing regions.

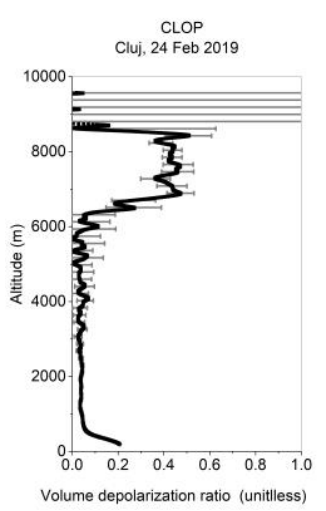

a

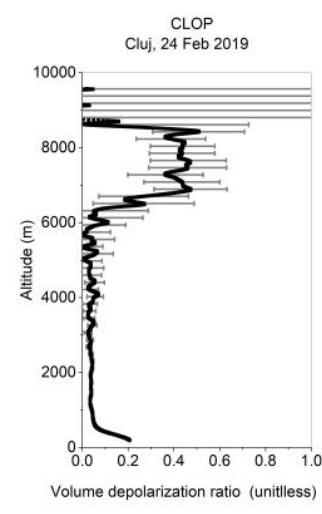

b
Figure 1 Depolarization profile for 24 of February 2019 a) systematic retrieval error not included b) systematic retrieval error included

\section{CONCLUSIONS}

The retrieval of the depolarization calibration constant is an important procedure since the accuracy of the constant can have a great influence on the depolarization value of the high depolarizing layers (either linear volume or particle depolarization products).

The time series of the depolarization calibration constant could be used as a stability indicator. Changes to the lidar instrument could easily be seen in the time series.

\section{ACKNOWLEDGEMENTS}

The research for this paper was financially supported by the ROSA STAR C3 contract no. $152 / 20.07 .2017$ - Satellite products validation using ground-based LIDAR stations - STRATUS.

The research for this paper was financially supported by the ROSA STAR C3 contract no.
183/05.09.2017 - Intelligent Software for Aerosol typing Based on Earth observation products, remote sensing measurements and transport modelling - ISABEL.

\section{REFERENCES}

[1] Bravo-Aranda, J. A., Belegante, L., Freudenthaler, V., Alados-Arboledas, L., Nicolae, D., Granados-Muñoz, et al.,: Assessment of lidar depolarization uncertainty by means of a polarimetric lidar simulator, Atmos. Meas. Tech., 9, 4935-4953, https://doi.org/10.5194/amt-94935-2016, 2016.

[2] G. Pappalardo, A. Amodeo, A. Apituley, A. Comeron, V. Freudenthaler, H. Linné, A. Ansmann, J. Bösenberg, G. D'Amico, I. Mattis, L. Mona, U. Wandinger, V. Amiridis, L. Alados-Arboledas, D. Nicolae, M. Wiegner, EARLINET: towards an advanced sustainable 20 European aerosol lidar network, Atmos. Meas. Tech. Discuss., 7(3) 29292980, (2014).

[3] L. Mona, Z. Liu, D. Muller, Lidar Measurements for Desert Dust Characterization: An Overview, Advances in Meteorology, (2012), ID356265.

[4] D. Nicolae, A. Nemuc, D. Muller, C. Talianu, J. Vasilescu, L. Belegante, A. Kolgotin, Characterization of fresh and aged biomass burning events using multiwavelength Raman lidar and mass spectrometry, J. Geophys. Res. Atmos., 118, (2013)

[5] Freudenthaler, V.: About the effects of polarizing optics on lidar signals and the $\Delta 90$ calibration, Atmos. Meas. Tech., 9(9), 4181-4255, doi:10.5194/amt-9-4181-2016, 2016.

[6] G. Pappalardo, L. Mona, G. D'Amico, U. Wandinger, M. Adam, A. Amodeo, A. Ansmann, A. Apituley, L. Alados Arboledas, D. Balis, A. Boselli, J. A. Bravo-Aranda, A. Chaikovsky, A. Comeron, J. Cuesta, F. De Tomasi, V. Freudenthaler, M. Gausa, E. Giannakaki, H. Giehl, A. Giunta, I. Grigorov, S. Groß, M. Haeffelin, A. Hiebsch, M. Iarlori, D. Lange, H. Linné, F. Madonna, I. Mattis, R.-E. Mamouri, M.A.P. McAuliffe, V. Mitev, F. Molero, F. Navas-Guzman, D. Nicolae, A. Papayannis, M.R. Perrone, C. Pietras, G. Pietruczuk, Pisani, J. Preißler, M. Pujadas, V. Rizi, A. Ruth, J. Schmidt, F. Schnell, P. Seifert, I. Serikov, M. Sicard, V. Simeonov, N. Spinelli, K. Stebel, M. Tesche, T. Trickl, X. Wang, F. Wagner, M. Wiegner, K.M. Wilson, Four-dimensional distribution of the 2010 Eyjafjallajökull volcanic cloud over Europe observed by EARLINET, Atmos. Chem. Phys. Discuss., 12, 30203- 30257, (2012). 